DOI https://doi.org/10.18551/rjoas.2020-10.13

\title{
SUITABILITY AND CARRYING CAPACITY ANALYSIS OF VANAME SHRIMP (LITOPENAEUS VANNAMEI) AQUACULTURE IN TEGAL, CENTRAL JAVA, INDONESIA
}

\author{
Riyanto* \\ Master's Study Program, Faculty of Fisheries and Marine Sciences, University of Brawijaya, \\ Malang, Indonesia
}

Sartimbul Aida, Sambah Abu Bakar

Faculty of Fisheries and Marine Sciences, University of Brawijaya, Malang, Indonesia

*E-mail: riy1983anto@gmail.com

\begin{abstract}
Tegal Regency the one of center vaname shrimp aquculture in Central Java. The number of production to increased which 1,560 ton (2014) to 618,593 ton (2017). The study of aim to determine the suitability of vaname shrimp farming land has collected and Geographic Information System (GIS) software was combined with the Analytical Hierachy Process (AHP). The assessment consists of ;(1) water quality consisting as temperature, $\mathrm{DO}, \mathrm{pH}$, salinity, brightness, ammonia, phosphate, and alkalinity; (2) soil quality consisting as soil $\mathrm{pH}$, potential redox, organic matter, texture and cation exchange capacity (CEC). Results of the assessment carried out on the coastal land of Tegal Regency, the potential obtained with the carrying capacity of land which is very suitable for vaname shrimp culture area is 1,533 ha or $27.10 \%$, according to 4,120 ha or $72.83 \%$ and sufficiently suitable for 4 ha or $0.07 \%$. The analysis carried out on the aquaculture area was obtained according to the very suitable classification data obtained 42 hectares of area, according to an area of 503 ha, and quite in accordance with the area of 2 hectares. Analysis showed aquaculture area is still in the appropriate category. It is necessary to increase production by restructuring the ponds to become more intensive. Corresponding Spatial Plan Tegal, Minapolitan to progression vaname shrimp farming is in District Warureja, Suradadi and Kramat.
\end{abstract}

\section{KEY WORDS}

Aquaculture, overlay, GIS, suitability, vaname.

Tegal Regency; one area in northern Central Java with an area of 878, $79 \mathrm{~km} 2$ and 3 (three) sub-districts in the north coast of Java, namely Kramat, Suradadi, and Warureja Districts. Tegal Regency is important in the development of fishery production, because it is strategically located in the coastal waters and distribution channels between provinces in Java Island (Mustafa 2012). Utilization of brackish fisheries is carried out through a mature arrangement and adjusted to the technical requirements of fishery cultivation, local sociocultural factors and the Regional Spatial Plan (RTRW) so that the sustainability of aquaculture is maintained (Dahuri 2001; Farkan and Mulyono 2020).

The failure of pond aquaculture has been experienced by cultivators on the coast of Tegal Regency in 1999, the tiger prawn commodity (Panaeus monodon) started in early 1984 and resulted in the cultivators not being utilized by the ponds (Fauzi, Susilo, and Mayasari 2009). Although later there are those who use it for growing milkfish (Chanos chanos Forskal) and seaweed cultivation (Wafi et al. 2019; Adam, Maftuch, and Hardoko 2013).

The advent of superior commodities vaname shrimp (Litopenaeus vannamei) July 12 , 2001 through a decree of the Minister of Marine Affairs and Fisheries No. 41/2001, the beginning farmer glanced shrimp commodities as biota kultivan (Fauzi, Susilo, and Mayasari 2009). But the development is very slow until the advent of technology BUSMETIK (Shrimp Farming Pond Plastic Mini System) was introduced. Opening of cultivated land into a new 
trend with the problem due to lack of consideration of the balance of the ecosystem, spatial patterns and other technical requirements related to the potential success and sustainability pennunjang area businesses.

The policy for developing the coastal area of Tegal Regency is the responsibility of the regional government through related parties in making an area development strategy according to Law No. 22 of 1999 concerning Regional Government. Information related to the utilization potential of the region is necessary, so that should be an analysis of the suitability and land capacity vaname shrimp aquaculture to be maximized and sustained.

Analysis of the technical potential of the region can be done by using Geographic Information System (GIS) to provide an assessment of the degree of suitability following an analysis of the hierarchy (Hossain et al. 2009; Pasongli, Dirawan, and Suprapta 2015; Syaugy, Siregar, and Arhatin 2017). Parameter constituent shrimp farming land suitability analysis vaname in accordance with importance (Analytical Hierarchy Process) in determining priorities for preparing hierarchy interests of each parameter (Meaden and Aguilar-Manjarrez 2013). On the basis of these considerations, it is necessary to have research on the analysis of the suitability and carrying capacity of the land in utilizing the coastal area of Tegal Regency as a center for vannamei shrimp cultivation so that cultivation activities can run optimally and sustainably.

\section{MATERIALS AND METHODS OF RESEARCH}

The experiment was conducted in March and June 2019 which includes primary data and secondary data. The primary data of water quality data, soil quality, and biophysical obtained in situ and ex situ in three (3) sub-district in the area of the District of Kramat Tegal district, sub-district and District Suradadi Warureja. Secondary data, production, land use maps and quality standards of water and soil quality as a support was obtained from the literature as well as research institutions or agencies.

Analysis of Spatial Distribution of Land Suitability Parameters. Stages in analyzing the parameters of the spatial distribution of land carrying capacity of the coastal area of Tegal through Geographic Information System-step approach. Analysis of the spatial distribution of land carrying capacity parameter itself consists of several activities, namely: the determination of the suitability of biophysical variables, soil and water, creation of base maps, digitization, scoring suitability variable values, interpolation to obtain distribution maps suitability value of each parameter cultivated land suitability in Figure 1.

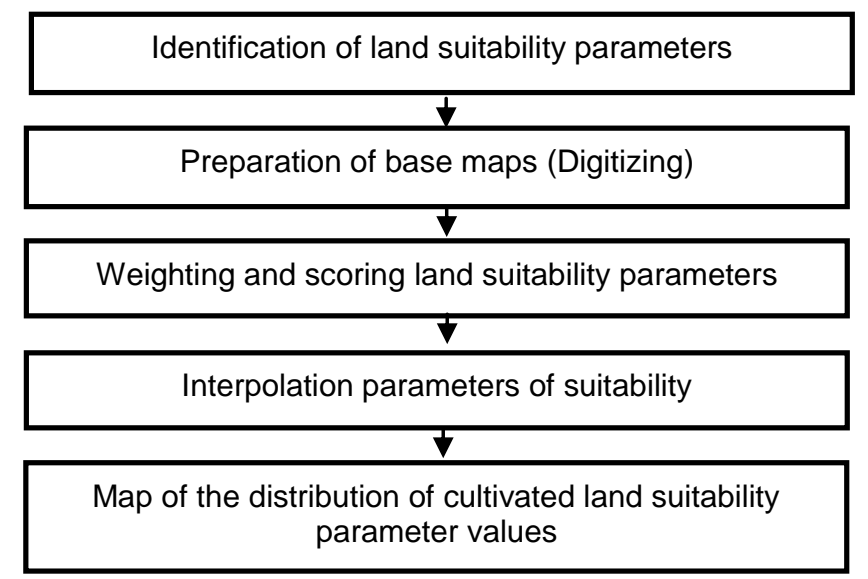

Figure $1-$ Stages of the spatial distribution analysis of land suitability parameters

The resulting digitized later in the form of thematic maps which will then be used in processing the data from the study with GIS analysis. The next step after data input is to make a thematic map of the land bearing capacity parameters. Inverse Distance Weighted (IDW) method is often used in interpolating data in coastal areas. An overview of the 
interpolation method in the form of a map distribution parameter with the degradation of land supporting a different color which indicates the value of each parameter.

Suitability Analysis Region Coastal Shrimp Vaname in Tegal. Analysis of the suitability of milkfish and shrimp cultivation area vaname aims to acquire land suitability map milkfish and shrimp aquaculture vaname. The data used is biogeophysical data obtained from research. The stages in analyzing the land suitability of the milkfish and shrimp cultivation are as follows: (1) making a basic thematic map; (2) input of thematic maps of land bearing capacity parameters; (3) scoring and weighting; (4) suitability class classification; (5) overlay (Overlay); (6) GIS analysis. Scheme stages of shrimp farming land suitability analysis.

- Thematic Mapping Capability Parameters of Land. The stages of making a thematic map of the carrying capacity parameters of the land have been described in section 1 and discussed in Figure 1. The thematic map of the parameters of the carrying capacity of the land then becomes the base map before inputting the parameter data of the carrying capacity of the land obtained from the research.

- Input Data Parameters of Land Carrying Capacity. Sources of data used in inputting data are data taken during research. The stages in inputting data are: (1) preparing a new layer, (2) inputting the thematic map (3) inputting the coordinates of the observation station and the observed parameter values. The data has been input and then in the nearest neighbor interpolation method so that the parameter data carrying capacity of the land into an area (polygon) so the shades will describe the differences of each parameter value.

- Scoring and Weighting. Methods of literature and justification of the competent authorities of marine and fishery be used in scoring and weighting of each parameter on the suitability of cultivated land. The scoring is based on the suitability level of the land carrying capacity parameter. The classification of the score is 1 (not suitable), score 2 (quite suitable), score 3 (suitable) and score 4 (very suitable). Weighting is done by using AHP analysis.

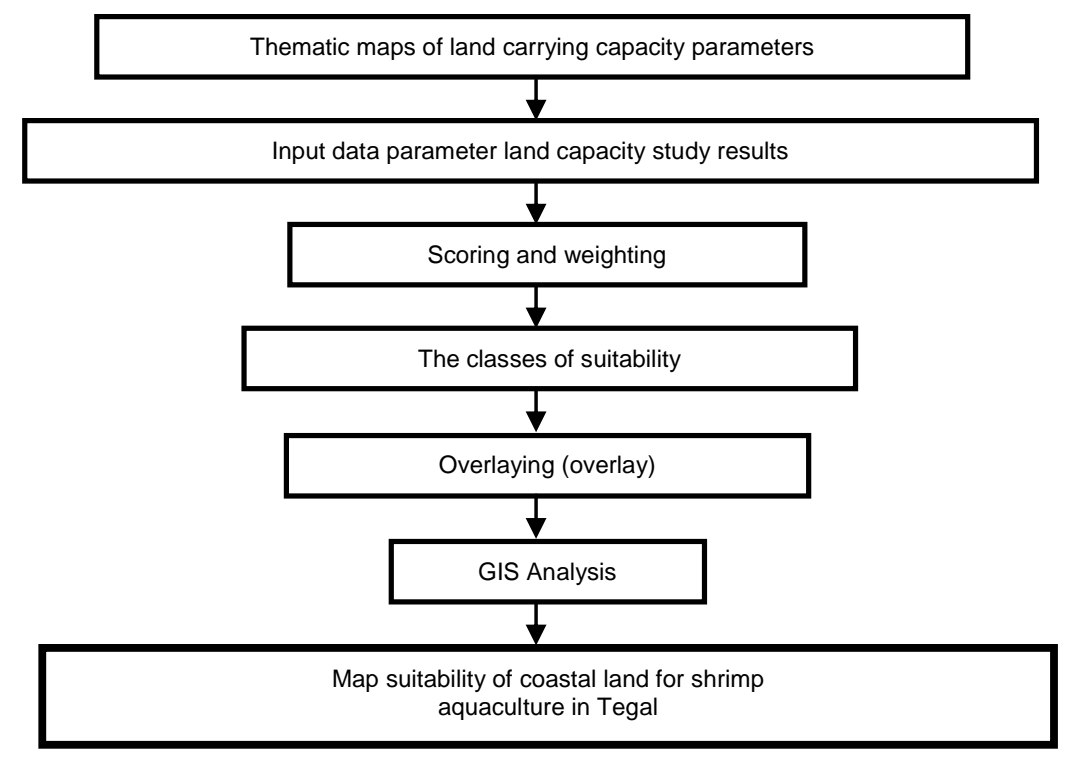

Figure 2 - Stages of land suitability analysis

- Classification Class Compliance. The purpose of the suitability class classification is to classify the carrying capacity parameter data of land based on their respective suitability levels. With this classification can be known class suitability of any parameter that is measured by multiplying the score with a weight that was grouped first through AHP analysis. The suitability class itself will be used in the operation of overlaying (overlay) begins its designation of the most important parameters (the greatest weight) sequence until the parameters are less important, so that will bring up a map corresponding potential land suitability. 
Table 1 - Hierarchy of water quality parameters

\begin{tabular}{lllll}
\hline No. & Parameters & Weight (\%) & Score & Description \\
\hline 1 & Temperature & 33,3 & 15.962 & Very Suitable (S1) \\
2 & DO & 22,8 & 41.816 & Suitable (S2) \\
3 & pH water & 10,5 & 77 & Quite suitable (S3) \\
4 & Ammonia & 10,5 & & \\
5 & Salinity & 10 & & \\
6 & Phosphate & 5 & & \\
7 & Alkalinity & 4,1 & & \\
8 & Clarity & 3,1 & & \\
\hline
\end{tabular}

\section{RESULTS AND DISCUSSION}

Analysis of suitability and carrying capacity of the land in coastal areas which do rural areas immediately adjacent to the beach either on land farms and vacant land as potential for development. As for the location and sampling stations at present in Figure 1.

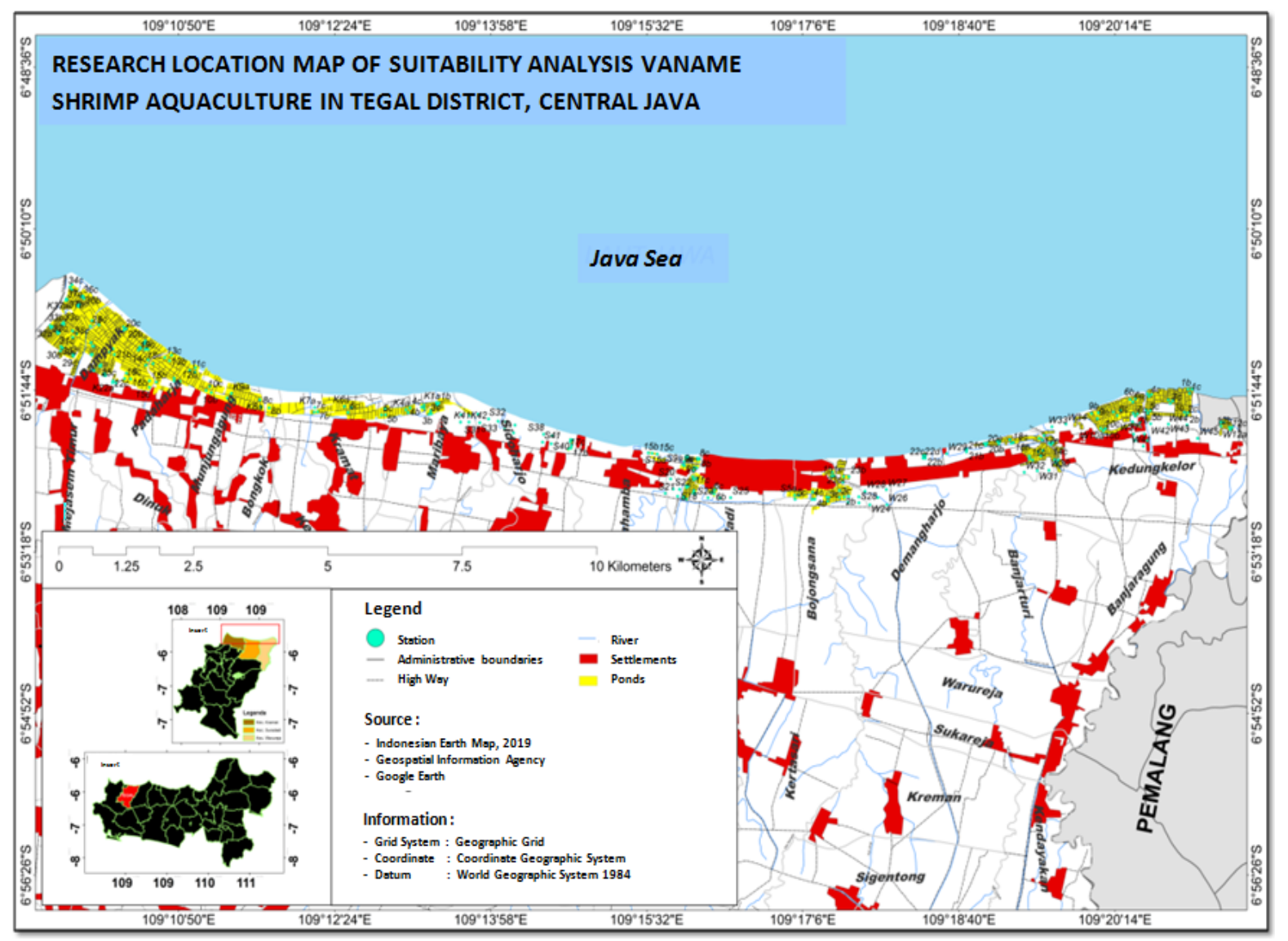

Figure 1 - Distribution of ponds and observation stations

Water Quality Compliance. Water quality conformance of an overlay of the entire water quality parameters acquired three land suitability classes shrimp ponds in Tegal is very appropriate $\mathrm{Ha} 1587$, pursuant $4,172 \mathrm{Ha}$, and quite fit $7 \mathrm{Ha}$. Hierarchy of water quality parameters are presented in Table 1.

Suitability of Soil Quality. Analysis of soil quality through the overlay stage resulted in 2 (two) classes of suitability, namely very suitable for an area of $722 \mathrm{Ha}$ and in accordance with a land area of $5.048 \mathrm{Ha}$. Based on the quality of the soil, the Tambak area of Tegal Regency is said to be good because the results of the analysis show that there are only 2 (two) classes of suitability, namely very suitable and suitable. Based on the hierarchy in Table 2, soil pH has the greatest weight with a percentage of $44.9 \%$. 
Table 2 - Hierarchy suitability of soil quality

\begin{tabular}{lllll}
\hline No. & Parameters & Weight $(\%)$ & Score & Description \\
\hline 1 & pH soil & 44,9 & 7.248 & Very suitable (S1) \\
2 & Potential redox & 24,5 & 50.607 & Suitable (S2) \\
3 & Soil texture & 15,6 & & \\
4 & Organic matter & 9,2 & & \\
5 & Cation exchange capacity & 5,8 & & \\
\hline
\end{tabular}

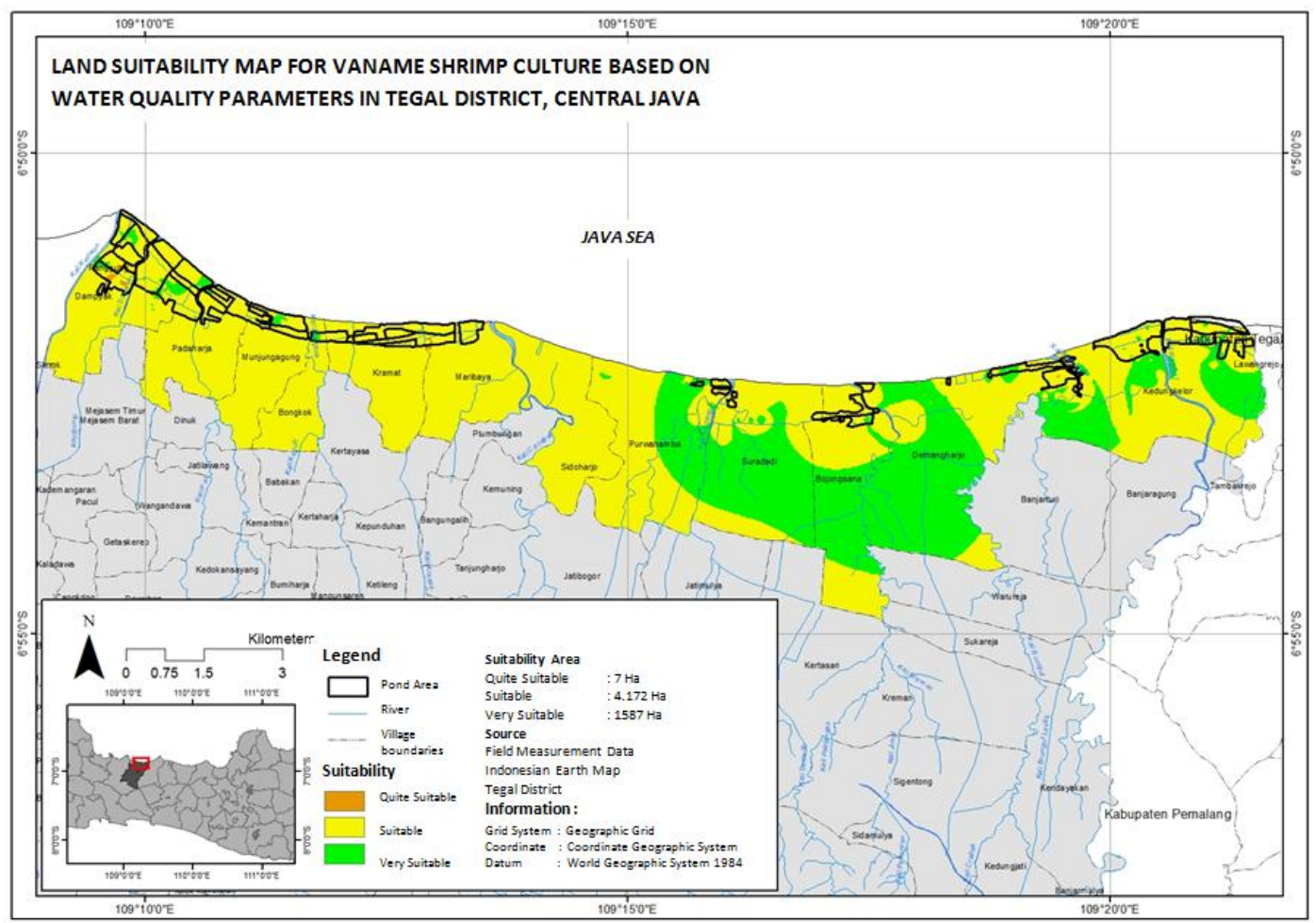

Figure 2 - Map of the suitability of water quality in the coastal Tegal

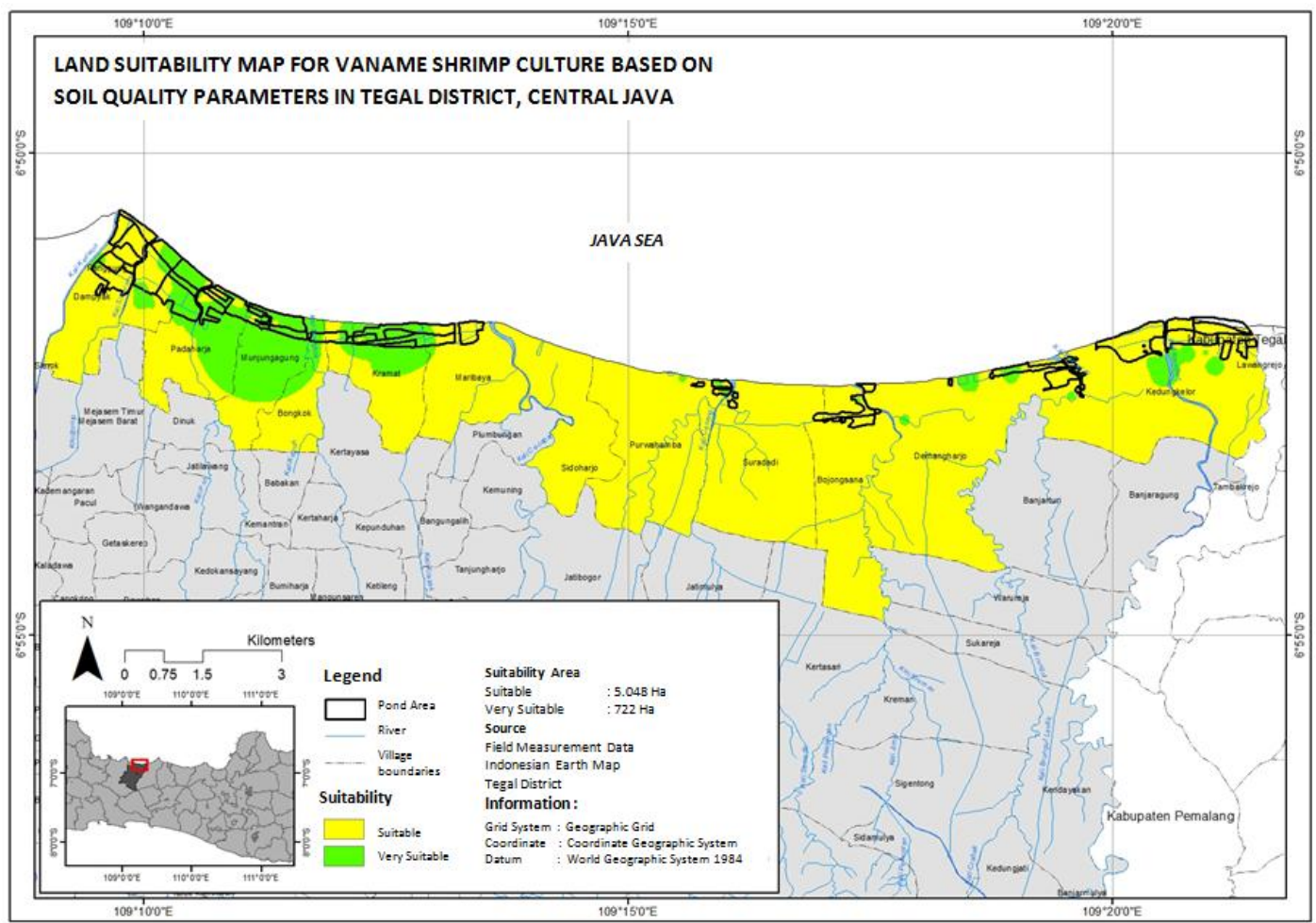

Figure 3-Map of the suitability of the soil quality in the coastal ponds Tegal 
Soil $\mathrm{pH}$ can affect the $\mathrm{pH}$ of the water in the maintenance medium in addition to affecting the speed of decomposition of organic matter. The $\mathrm{pH}$ value of water is influenced by oxygen concentration, temperature, alkalinity and anions and cations in the waters (Suhaimi, Hasnawi, and Ratnawati 2016; Mustafa 2008; Husein 2003). The pH itself in the waters shows the concentration of hydrogen $(\mathrm{H}+)$ and $\mathrm{OH}$ - ions in the water. The $\mathrm{pH}$ value will affect the activity of biochemical reactions in shrimp bodies, chemical reactions in water bodies, the toxicity of a compound, survival rates and growth rates of shrimp (Suwarsih et al. 2016).

Suitability Biogeography. The compilers of the biobiogeophysical suitability component in this study consisted of 4 (four) parameters, namely the distance from the coast, the distance from the river, the depth and the slope of the land. As in the previous parameters, these biobiogeophysical parameters are also processed based on the hierarchy assessed by AHP which is presented in Table 3. The results of the AHP assessment show that the distance from the beach is the first priority with a weight of $50.8 \%$ and slope is in the last order with weights $7.5 \%$.

Table 3 - Hierarchy of biogeophysical suitability

\begin{tabular}{lllll}
\hline No. & Parameters & Weight (\%) & Score & Description \\
\hline 1 & Distance from coastal & 50,8 & 786 & Very suitable (S1) \\
2 & Distance from rivers & 26,5 & 4.394 & Suitable(S2) \\
3 & Depth & 15,1 & 10.393 & Quite suitable (S3) \\
4 & Slope & 7,5 & 401 & Not suitable (S4) \\
\hline
\end{tabular}

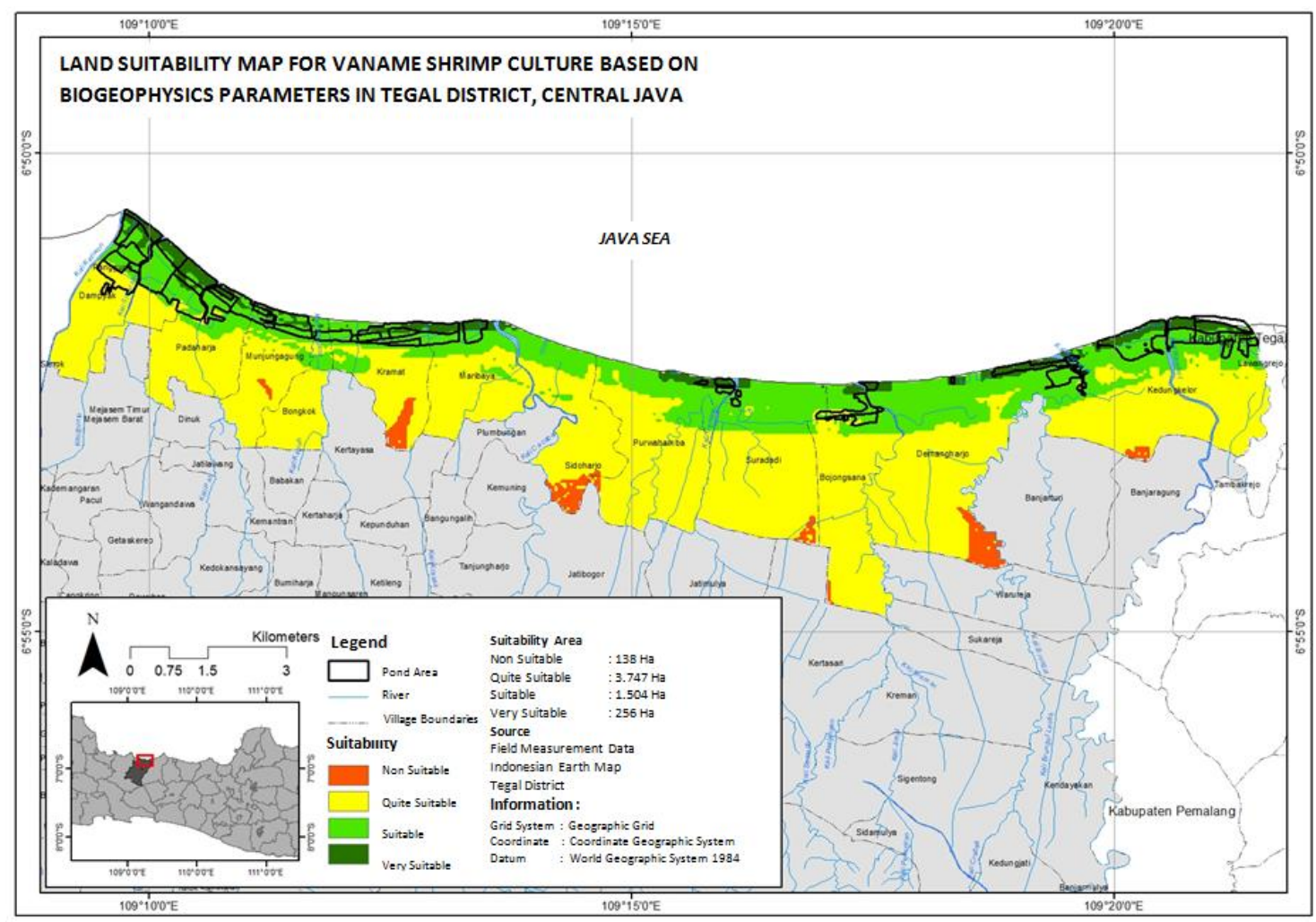

Figure 4 - Map of ponds in the coastal biophysical suitability Tegal

The results of the suitability analysis by overlaying all the biogeophysical parameters obtained 4 (four) land suitability classes, namely very suitable for an area of $256 \mathrm{Ha}$, corresponding to an area of $5.048 \mathrm{Ha}$, quite suitable for an area of $3,747 \mathrm{Ha}$, and not suitable for an area of $138 \mathrm{Ha}$. The parameter with the highest weight is proximity to beaches and rivers because shrimp farming activities must be supported by easy access to source water, both sea water and fresh water (Marsuki, Tamsil, and Ihsan 2019; Ristiyani 2013; Syaugy, Siregar, and Arhatin 2017). 
Table 4 - Hierarchy of land carrying capacity parameters

\begin{tabular}{lllll}
\hline No. & Parameters & Weight (\%) & Score & Description \\
\hline 1 & Water quality & 63,7 & 4.505 & Very suitable (S1) \\
2 & Soil quality & 25,8 & 11.998 & Suitable(S2) \\
3 & Biogeophysical & 10,5 & 17 & Quite suitable (S3) \\
\hline
\end{tabular}

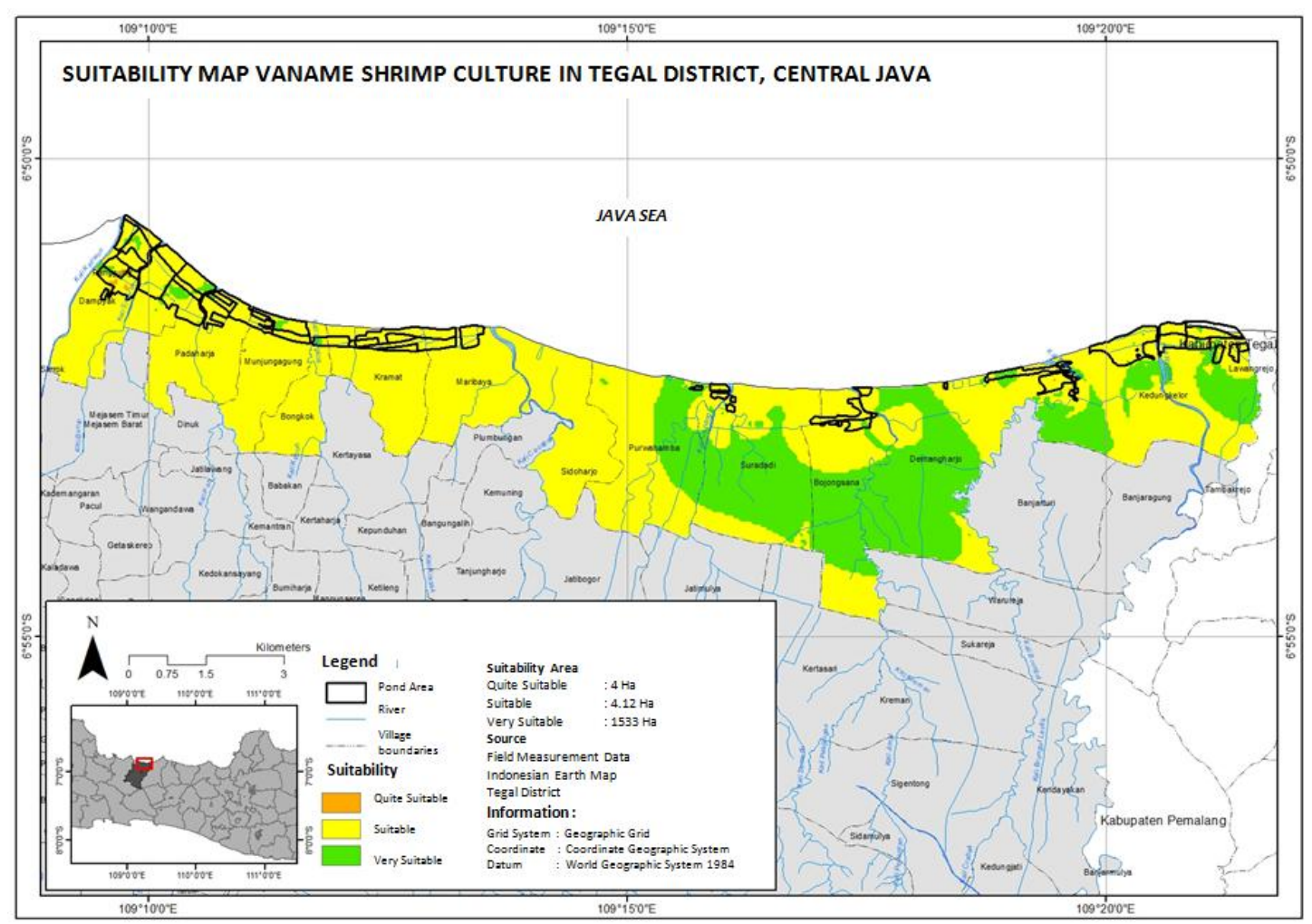

Figure 5 - Map of suitability of the carrying capacity of ponds on the coast of Tegal Regency

Table 5 - Suitability level of pond land

\begin{tabular}{clcccc}
\hline \multirow{2}{*}{ No } & Suitability & \multicolumn{4}{c}{ Area (Ha) per Conformity Class } \\
\cline { 2 - 5 } 1 & Water quality & S1 & S2 & S3 & S4 \\
\hline 2 & Soil quality & 722 & 5172 & 7 & \\
\hline 3 & Biogeophysical & 256 & 15048 & 3747 & 138 \\
\hline 4 & Carrying capacity & 1533 & 4120 & 4 & \\
\hline
\end{tabular}

Suitability of the carrying capacity of ponds. Suitability of land supporting the farm is done by overlaying operation of the three criteria, namely the suitability parameters of water quality, soil quality and biogeophysical where the hierarchy for all three criteria is the quality of the water has the greatest weight by $63.7 \%$ and the smallest is the biophysical criteria with weights $10,5 \%$ (Table 4). Overlay results obtained from three (3) land suitability classes based on the three parameters above is highly appropriate category covering 1,533 hectares, 4,120 hectares correspond, quite appropriate $4 \mathrm{Ha}$.

\section{CONCLUSION}

Results of analysis showed aquaculture area is still in the appropriate category. It is necessary to increase production by restructuring the ponds to become more intensive. Corresponding Spatial Plan Tegal, Minapolitan to progression vaname shrimp farming is in District Warureja, Suradadi and Kramat. 


\section{REFERENCES}

1. Adam, Moh Awaludin, Maftuch Maftuch, and Hardoko Hardoko. 2013. "Aktivitas Antibakteri Ekstrak Fenol Gracillaria Verrucosa Terhadap Bakteri Aeromonas Salmonicida Secara in Vitro." Natural B 2 (1): 1-2. https://doi.org/10.21776/ub.naturalb.2013.002.01.2.

2. Dahuri, Rokhimin. 2001. "Pengelolaan Ruang Wilayah Pesisir Dan Lautan Seiring Dengan Pelaksanaan Otonomi Daerah." Jurnal Sosial Dan Pembangunan 17 (2): 13971. https://doi.org/https://doi.org/10.29313/mimbar.v17i2.38.

3. Farkan, Moch, and Mugi Mulyono. 2020. "Strategi Pengembangan Budidaya Udang Berkelanjutan Di Kawasan Pesisir Kota Tegal, Provinsi Jawa Tengah” 5 (April): 170-85.

4. Fauzi, Yulian, Boko Susilo, and Zulfia Memi Mayasari. 2009. "Analisis Kesesuaian Lahan Wilayah Pesisir Kota Bengkulu Melalui Perancangan Model Spasial Dan Sistem Informasi Geografis (SIG)." Forum Geografi $23 \quad$ (2): 101. https://doi.org/10.23917/forgeo.v23i2.5002.

5. Hossain, M. Shahadat, Sayedur Rahman Chowdhury, Nani Gopal Das, S. M. Sharifuzzaman, and Abida Sultana. 2009. "Integration of GIS and Multicriteria Decision Analysis for Urban Aquaculture Development in Bangladesh." Landscape and Urban Planning 90 (3-4): 119-33. https://doi.org/10.1016/j.landurbplan.2008.10.020.

6. Husein, Rahmad. 2003. "Konsep Dasar Sistem Informasi Geografis (geographics information system)," 1-9.

7. Marsuki, Mustainah, Andi Tamsil, and Ihsan. 2019. "Analisis Aspek Biofisik Dan Kimia Perairan Untuk Pengembangan Budidaya Tambak Di Wilayah Pesisir Kecamatan Pedongga Kabupaten Pasangkayu Sulawesi Barat" 2 (1): 56-67.

8. Meaden, Geoffer J, and José Aguilar-Manjarrez. 2013. Advances in Geographic Information Systems and Remote Sensing for Fisheries and Aquaculture. FAO Technical Paper. http://www.fao.org/docrep/field/003/ab825f/AB825F00.htm\#TOC.

9. Mustafa, Akhmad. 2008. "Desain, Tata Letak, Dan Konstruksi Tambak." Media Akuakultur 3 (2): 166. https://doi.org/10.15578/ma.3.2.2008.166-174.

10. 2012. "Kriteria Kesesuaian Lahan Untuk Berbagai Komoditas Di Tambak." Media Akuakultur 7 (2): 108. https://doi.org/10.15578/ma.7.2.2012.108-118.

11. Pasongli, Hernita, Gufran D Dirawan, and Suprapta. 2015. "Zonasi Kesesuaian Tambak Untuk Pengembangan Budidaya Udang Vaname (Penaeus Vannamei) Pada Aspek Kualitas Air Di Desa Todowongi Kecamatan Jailolo Kabupaten Halmahera Barat." Jurnal Bioedukasi 3 (2): 324-35.

12. Ristiyani, Dwi. 2013. "Evaluasi Kesesuaian Lahan Untuk Budidaya Perikanan Tambak Di Pesisir Kendal." Geo-Image 2 (1). https://doi.org/10.15294/geoimage.v2i1.235.

13. Suhaimi, Rezki Antoni, Hasnawi Hasnawi, and Erna Ratnawati. 2016. "Kesesuaian Lahan Untuk Budidaya Udang Windu (Penaeus Monodon) Di Tambak Kabupaten Brebes, Jawa Tengah." Jurnal Riset Akuakultur 8 (3): 465. https://doi.org/10.15578/jra.8.3.2013.465-477.

14. Suwarsih, Marsoedi, Nuddin Harahab, and Mohammad Mahmudi. 2016. "Kondisi Kualitas Air Pada Budidaya Udang Di Tambak Wilayah Pesisir Kecamatan Palang Kabupaten Tuban." Prosiding Seminar Nasional Kelautan 2016, 138-43.

15. Syaugy, Afwan, Vincentius P. Siregar, and Risti Endriani Arhatin. 2017. "Evaluasi Kesesuaian Lahan Tambak Udang Di Kecamatan Cijulang Dan Parigi, Ciamis, Jawa Barat." Jurnal Teknologi Perikanan Dan Kelautan 3 (2): 43-56. https://doi.org/10.24319/jtpk.3.43-56.

16. Wafi, A, A.B. Sambah, M.A. Adam, and M. Mahmudi. 2019. "Carrying Capacity Analysis of the Environment At Coastal the District Banyuputih Situbondo To the Development Cultivation of Cottonii Seaweed (Eucheuma Cottonii)." Russian Journal of Agricultural and Socio-Economic Sciences 94 (10): 100-107. https://doi.org/10.18551/rjoas.201910.13 . 